\title{
Holmium:YAG Laser for Treatment of Strictures of Vesicourethral Anastomosis after Radical Prostatectomy
}

\author{
BRUNOLF W. LAGERVELD, M.D., M. PILAR LAGUNA, M.D., FRANS M.J. DEBRUYNE, M.D., \\ and JEAN J.M.C.H. DE LA ROSETTE, M.D.
}

\begin{abstract}
Background and Purpose: Strictures of the vesicourethral anastomosis (VUA) following radical prostatectomy tend to recur. We used the holmium:YAG laser for treatment of recurrent stricture of the VUA. We evaluated the technique and its efficacy.

Patients and Methods: In 10 patients, the Ho:YAG laser was used with a 365- $\mu \mathrm{m}$ fiber at a setting of $2 \mathrm{~J}$ and frequency 10 to $20 \mathrm{~Hz}$, creating a deep incision of the scar tissue at the 6 o'clock position. This was followed by a vaporizing resection of the remaining scar tissue between 3 and 9 o'clock. We aimed to vaporize up to well-vascularized surrounding tissue. Retrospectively, the charts were reviewed for hospital stay, voiding complaints, recurrence of stenosis, complications, and flow rates. The mean follow-up was 18 months.

Results: There were no operative complications. After removal of the catheter, all patients could void without difficulty. No re-treatment was needed for recurrent stenosis. Any existing irritative voiding complaints or incontinence did not change after treatment. In all patients, the flow pattern improved: the mean maximum flow rate increased, and the mean postvoiding residual volume decreased.

Conclusion: The Ho:YAG laser seems to be a safe and effective treatment for first or recurrent strictures of the VUA after radical prostatectomy.
\end{abstract}

\section{INTRODUCTION}

$\mathbf{P}$ ROSTATE CANCER is one of the most common cancers in men. Since the introduction of prostate specific antigen (PSA) and improved prostate-biopsy strategies, the incidence of organ-confined prostate cancer detected earlier in younger patients has increased dramatically. ${ }^{1}$ Consequently, the number of surgically treated prostate cancers has increased as well. Postoperative complications and side effects, such as incontinence and loss of erectile function, are well known and frequently reported in the literature. However, the next most common complication is stricture of the vesicourethral anastomosis (VUA), with rates ranging from $8.6 \%$ to $17.9 \% .^{2-4}$ These strictures tend to have a high incidence of recurrence and can have a tremendous impact on the quality of life of the patients. Several treatment options, such as dilatation, endoscopic cold-knife incision, endoscopic electrocautery incision or resection, and intermittent self-catheterization, are commonly used. It is suggested that the treatment of urethral strictures using the holmium:YAG laser is favorable. ${ }^{5}$ However, to our knowledge, the Ho:YAG laser has only once been used for treatment of a recurrent stricture of the VUA following retropubic radical prostatectomy. ${ }^{5}$ In this paper, we describe our technique and results.

\section{PATIENTS AND METHODS}

\section{Patients}

From 2000 to 2002, in 10 patients, the Ho:YAG laser was used for the treatment of VUA stenosis following open radical retropubic prostatectomy (RRP). These patients were not specifically selected for the laser treatment. All symptomatic patients with a primary or a recurrent stenosis after RRP who underwent laser therapy were included for evaluation. In all cases, the diagnosis of VUA stenosis was confirmed with urethroscopy. Patients with suspicion of local recurrence of prostate cancer were not excluded. Hormonal therapy for systemic or local recurrence or adjuvant radiotherapy of the formal prostatic region was likewise no reason for exclusion.

Department of Urology, Academic Medical Center University of Amsterdam, Amsterdam, The Netherlands. 
Table 1. Characteristics of Patients with Strictures after Radical Prostatectomy

\begin{tabular}{|c|c|c|c|c|c|c|}
\hline Patient & $\begin{array}{l}\text { Bladder-neck } \\
\text { reconstruction }\end{array}$ & $T N M$ & $\begin{array}{c}\text { Gleason } \\
\text { sum/grade }\end{array}$ & $\begin{array}{c}\text { Post-RRP } \\
\text { radiotherapy }\end{array}$ & $\begin{array}{l}\text { Pre RRP } \\
\text { hormonal } \\
\text { treatment }\end{array}$ & $\operatorname{Rec}^{\mathrm{a}}$ \\
\hline $1^{b}$ & Unknown & $\mathrm{pT}_{2} \mathrm{~N}_{0} \mathrm{M}_{\mathrm{x}}$ & "Intermediate" & - & - & - \\
\hline 2 & + & $\mathrm{pT}_{3 \mathrm{~b}} \mathrm{~N}_{0} \mathrm{M}_{\mathrm{x}}$ & 9 & $+^{\mathrm{d}}$ & - & + \\
\hline 3 & + & $\mathrm{pT}_{3} \mathrm{~N}_{0} \mathrm{M}_{\mathrm{x}}$ & 5 & + & - & + \\
\hline 4 & + & $\mathrm{pT}_{2 \mathrm{~b}} \mathrm{~N}_{0} \mathrm{M}_{\mathrm{x}}$ & 7 & + & - & - \\
\hline 5 & + & $\mathrm{pT}_{2 \mathrm{a}} \mathrm{N}_{0} \mathrm{M}_{\mathrm{x}}$ & 6 & - & - & - \\
\hline 6 & $+^{\mathrm{c}}$ & $\mathrm{pT}_{2 \mathrm{~b}} \mathrm{~N}_{0} \mathrm{M}_{\mathrm{x}}$ & 6 & - & + & - \\
\hline 7 & + & Dysplasia & - & - & - & - \\
\hline 8 & + & $\mathrm{pT}_{3 \mathrm{~b}} \mathrm{~N}_{1} \mathrm{M}_{0}$ & 5 & + & - & - \\
\hline $9^{\mathrm{b}}$ & Unknown & $\mathrm{pT}_{2 \mathrm{~b}} \mathrm{~N}_{0} \mathrm{M}_{\mathrm{x}}$ & "Intermediate" & - & - & - \\
\hline 10 & + & $\mathrm{pT}_{2 \mathrm{~b}} \mathrm{~N}_{0} \mathrm{M}_{\mathrm{x}}$ & 6 & + & - & - \\
\hline
\end{tabular}

aProven local recurrence.

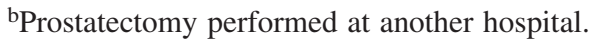

${ }^{\mathrm{c}}$ Anastomosis was very fragile.

dPatient also received bicalutamide for 6 months.

All patients, except for one with dysplasia, had a stage pT2 to pT3b (Gleason sum 5-9) prostate cancer. Resection margins were positive in $50 \%$, of whom one received adjuvant radiotherapy and bicalutamide. Later, in two of these five patients, recurrent local disease was confirmed with biopsy. At the time of RRP, a bladder-neck reconstruction had been performed in all patients except three. In one, the bladder neck has been preserved. Two others were referred to our hospital because of micturition problems after radical prostatectomy.

In all cases, before establishing the VUA with five interrupted sutures, the bladder mucosa was everted with interrupted absorbable sutures. Furthermore, if bladder-neck reconstruction was needed, it was performed by narrowing sutures at the dorsal side. In one case, there was a technical difficulty in realizing a reliable VUA (Table 1). In all RRPs, there was no case of excessive bleeding ( $\geq 1 \mathrm{~L}$ ). Prolonged urinary leakage at the site of the anastomosis occurred in one case.

From the beginning, after removal of the transurethral catheter, all patients were able to void with a fair stream. Later, each patient suffered from a weak stream and prolonged voiding time.
No signs of upper urinary-tract deterioration were noted when a significant postvoiding residual volume was found.

Six patients had been treated for strictures at the anastomosis with dilatation, clean intermittent self-catheterization, and cold-knife urethrotomy. Suffering from recurrences, four of these patients had been treated more than once and with several modalities (Table 2). The time of initial diagnosis of stricture of the VUA ranged from 1 to 36 months (mean 8.7 months) after prostatectomy.

All laser endourethrotomies were performed by the same urologist. In a retrospective manner, the charts of these 10 patients were reviewed. The outcomes of hospital stay, voiding complaints, recurrence of stenosis, complications, and flow rates after a vaporizing holmium laser treatment for a VUA stenosis were evaluated. All operative reports were studied for technical details.

\section{Technique}

With the patient under general or regional anesthesia, a $17 \mathrm{~F}$ rigid endoscope with a $365-\mu \mathrm{m}$ end-firing laser fiber was used

Table 2. Previous Modalities and Number of Treatments

\begin{tabular}{ccccc}
\hline Patient & No treatment & $\begin{array}{c}\text { Sachse } \\
\text { urethrotomy }\end{array}$ & Dilatation & $\begin{array}{c}\text { Intermittent } \\
\text { self-catheterization }\end{array}$ \\
\hline 1 & $\mathrm{X}$ & - & - & - \\
2 & - & - & 1 & - \\
3 & - & 3 & 1 & - \\
4 & - & 1 & 1 & - \\
5 & - & - & - & - \\
6 & $\mathrm{X}$ & - & - & - \\
7 & $\mathrm{X}$ & - & - & - \\
9 & $\mathrm{X}$ & - & - & 1 \\
\hline
\end{tabular}

aThis patient had persistent urinary leakage at site of anastomosis for 3 weeks after radical prostatectomy. 
Table 3. Time from Radical Prostatectomy to Stricture and Laser Treatment

\begin{tabular}{ccccc}
\hline Patient & $\begin{array}{c}\text { Stricture diagnosis } \\
\text { after RRP (months) }\end{array}$ & $\begin{array}{c}\text { Age at time of laser } \\
\text { (years) }\end{array}$ & $\begin{array}{c}\text { Time from RRP } \\
\text { to laser (mos) }\end{array}$ & $\begin{array}{c}\text { Follow-up } \\
\text { (mos) }\end{array}$ \\
\hline 1 & 12 & 59 & 14 & 9 \\
2 & 19 & 60 & 20 & 25 \\
3 & 2 & 69 & 42 & 28 \\
4 & 2 & 64 & 8 & 3 \\
5 & 2 & 57 & 6 & 29 \\
6 & 1 & 69 & 9 & 28 \\
7 & 9 & 56 & 37 & 23 \\
8 & 1 & 68 & 41 & 22 \\
9 & 36 & 74 & 4 & 10 \\
\hline
\end{tabular}

with saline irrigation. The stricture at the anastomosis, and if possible the ureteral orifices, were identified. The Ho:YAG laser was used at a setting of $1 \mathrm{~J}$ with a frequency of $10 \mathrm{~Hz}(10$ W). According to the surgeon's preference, this could be increased during the procedure to $40 \mathrm{~W}(2 \mathrm{~J}, 20 \mathrm{HZ})$. A deep incision was made at the six o'clock position in the scar tissue of the anastomosis. Frequently, the scar tissue at the dorsal side was thicker and seemed to be more obstructing than at the ventral side of the anastomosis. Most of the time, the incision opened up the lumen. Following this, the scar tissue was vaporized. We aimed to remove all scar tissue between the 3 and 9 o'clock positions up to well-vascularized surrounding tissue. If scar tissue remained at the ventral side that might hinder urine flow, this was also resected by vaporization. A transurethral $18 \mathrm{~F}$ Foley catheter was placed for 1 day.

\section{RESULTS}

The mean follow-up after laser treatment was 18 months (range 3-29 months) (Table 3). There were no perioperative complications. The following day, all patients were discharged from the hospital after removal of the catheter. In all cases, they were able to void spontaneously without any difficulty and without significant postvoiding residual volume. During followup, no acute retention occurred, and so far, no re-treatment or intermittent self-catheterization has been needed for a recurrent stricture.

Before laser endourethrotomy, five patients were incontinent. All except one had stress incontinence. In one, sphincter deficiency was proven. None of these patients complained about worsening of the incontinence or was using more pads after laser endourethrotomy. There was no recording of standardized questionnaires or voiding diaries in the charts. Subjectively, according to the patients, irritative voiding complaints or incontinence that existed in advance of the laser treatment did not worsen afterward.

In four patients, there was subjective improvement of lower urinary-tract symptoms after laser treatment. In one of these patients, there was a slight improvement in the seriousness of the stress incontinence. At free flow, the flow pattern improved in all patients compared with the preoperative situation. One patient had a suprapubic catheter because of an almost complete stenosis of the anastomosis and was unable to void spontaneously in advance of laser treatment. In another patient, no free-flow study was performed before laser therapy (Table 4).

Table 4. Uroflow Data before and after Treatment

\begin{tabular}{|c|c|c|c|c|c|c|}
\hline \multirow[b]{2}{*}{ Patient } & \multicolumn{3}{|c|}{ Before laser therapy } & \multicolumn{3}{|c|}{ After laser therapy } \\
\hline & $\begin{array}{l}\text { Voided volume } \\
\qquad(m L)\end{array}$ & $\begin{array}{c}Q_{\max } \\
(\mathrm{mL} / \mathrm{sec})\end{array}$ & $\begin{array}{l}\text { Residual volume } \\
\qquad(m L)\end{array}$ & $\begin{array}{l}\text { Voided volume } \\
\qquad(m L)\end{array}$ & $\begin{array}{c}Q_{\max } \\
(\mathrm{mL} / \mathrm{sec})\end{array}$ & $\begin{array}{c}\text { Residual volume } \\
(\mathrm{mL})\end{array}$ \\
\hline 1 & 199 & 13.0 & 12 & 260 & 17.2 & 0 \\
\hline 2 & 177 & 5.0 & 161 & 588 & 16.0 & 38 \\
\hline 3 & 35 & 4.5 & 41 & 147 & 23.2 & 0 \\
\hline 4 & 99 & 3.0 & 0 & 122 & 8.0 & 0 \\
\hline 5 & 97 & 3.7 & 0 & 271 & 10.1 & 0 \\
\hline 6 & $0^{\mathrm{a}}$ & - & - & 258 & 24.6 & 0 \\
\hline 7 & 173 & 5.1 & 0 & 387 & 25.4 & $40(0)^{\mathrm{b}}$ \\
\hline 8 & 137 & 3 & 260 & 185 & 10.8 & 55 \\
\hline 9 & 200 & 8.0 & 0 & 170 & 22.4 & 0 \\
\hline 10 & Not performed & - & - & 40 & 21.2 & 0 \\
\hline
\end{tabular}

aPatient with almost complete stenosis and suprapubic catheter.

bThis patient had no residual volume after second micturition. 
The mean maximum flow rate increased from 5.7 to 19.0 $\mathrm{mL} / \mathrm{sec}$. Before treatment, four patients had a postvoiding residual, and the volume in the patient with a suprapubic catheter was estimated at $200 \mathrm{~mL}$. In these five patients, the mean residual volume decreased from 60 to $16 \mathrm{~mL}$. In no case did we find a decrease of the maximum flow rate or worsening of the postvoiding residual volume. In one patient, there was initially an increased postvoiding residual volume, but this patient had no residual volume after a second voiding shortly after the first attempt.

\section{DISCUSSION}

The open retropubic radical prostatectomy is a standardized curative procedure for organ-confined prostate cancer and is performed by many urologists all over the world. The morbidity of this operative technique is well emphasized in many studies. $^{2-4,6}$ The major concern after radical prostatectomy is the occurrence of erectile dysfunction and incontinence. However, potentially recurrent strictures of the VUA are not uncommon, the rate ranging from $8.6 \%$ to $17.9 \% .^{2-4}$ In daily practice, this means that we will be faced with this specific complication, which normally appears within a few months after surgery. ${ }^{4}$ Even in experienced hands, these complications are seen. ${ }^{4}$ Moreover, even with the excellent magnification available during laparoscopic radical prostatectomy, postoperative strictures can develop. ${ }^{7}$ In our series, there was a $50 \%$ positive-margin rate at radical prostatectomy, and two of these five patients had a proven recurrence of prostate cancer.

We do not recommend biopsies for patients with a symptomatic stricture because the outcome will not change the need for invasive treatment. Furthermore, to our knowledge, there is no correlation between the incidence of strictures of the anastomosis and cancer recurrence. In the follow-up, all patients will be screened for biochemical relapse, but this is of no consequence in determining whether invasive treatment is needed. Additional hormonal treatment is optional.

It is suggested that the technique of suturing might be important in the prevention of strictures. ${ }^{8}$ Preservation of the bladder neck results in a lower incidence of strictures. ${ }^{9}$ Other risk factors for strictures are a previous transurethral resection of the prostate, excessive intraoperative blood loss, and urinary extravasation at the anastomotic site. ${ }^{10,11}$ Although the oncologic outcome has an important influence on the quality of life after surgery, we should not underestimate the impact of surgical morbidity and complications. Severe recurrent strictures can lead to a urinary diversion or continent urinary stoma, not to mention bladder stones and recurrent urinary-tract infections because of postvoiding residual urine in the bladder. Dilatation of the stricture will tear scar tissue open in a less-controlled way and results in a high recurrence rate. Also, after dilatation, many patients remain dependent on regular clean intermittent self-catheterization. Invasive techniques under direct vision are better controlled. The strictures can be incised with a cold knife. However, resection of scar tissue is not possible, and a simple incision of the scar tissue of the stricture may not be enough to prevent recurrence. After incision, scar tissue can be resected with an electrocautery angled loop wire. On the other hand, because of the size of the wire, there is a risk of a too-deep re- section, which can lead to damage to collateral healthy tissue, including the external sphincter. Resection of all fibrous tissue will not only open the lumen but may result in a lower incidence of recurrence.

The holmium laser is another surgical device for tissue ablation. This minimally invasive device is used in urology for several other indications such as stone fragmentation, tissue ablation in the upper tract, and transurethral prostate incision and resection. ${ }^{12-14}$ The holmium laser is easy to handle. The endfiring fiber is light and flexible, and because of its small caliber, it can be used with a rigid and as well as a flexible endoscope. Under direct vision, with sufficient irrigant flow, which directly absorbs energy, a controlled incision and vaporizing of scar tissue can be performed. The urologist can control the firing pulses accurately with a foot switch. Therefore, damage to the collateral healthy tissue such as the rectal wall is unlikely, particularly because of the small fiber tip and the shallow depth of tissue penetration $(0.4 \mathrm{~mm}) .{ }^{14}$ In electrocautery resection, we use a monopolar current, which gives more diffuse tissue penetration of the heat. The holmium laser is safe to use, with no reported complications other than those known from the other available methods of surgical treatment of strictures. Hemostasis of small bleeding vessels can be obtained with the laser. This possibility is an advantage in patients with blood-clotting disorders. Patients suffer no particular discomfort after the procedure. An indwelling catheter can be removed soon after treatment.

In this group of 10 patients, we did not see any stricture recurrences. Even the patients who had been treated previously with more than one technique showed no evidence of recurrence. However, this number of patients is too small to draw the conclusion that no recurrences can develop. For this, a randomized controlled study with sufficient follow-up is needed. Nevertheless, the technique seems to be promising and may eventually be used as a first-line option in the treatment of VUA strictures after radical prostatectomy. The success of this technique is most probably based on the removal of the scar tissue on the one hand and, on the other hand, the prevention of recurrent stricture because of the favorable healing after laser surgery. Another explanation might be that healing might be less reactive at the bladder neck than, for example, more distally in the urethra. Kural and associates ${ }^{5}$ showed that recurrences can follow laser endourethrotomy of urethral strictures.

\section{CONCLUSION}

Holmium:YAG laser therapy seems to be a safe and effective minimally invasive treatment for even recurrent strictures of the VUA after radical prostatectomy. We postulate that the reduction of the recurrence rate in this indication is attributable to the fact that a laser incision is combined with vaporization of scar tissue.

\section{REFERENCES}

1. Han M, Partin AW, Plantadosi S, Epstein JI, Walsh PC. Era specific biochemical recurrence-free survival following radical prostatectomy for clinically localized prostate cancer. J Urol 2001; $166: 416-419$. 
2. Stanford JL, Feng Z, Hamilton AS, et al. Urinary and sexual function after radical prostatectomy for clinically localized prostate cancer. JAMA 2000;283:354-360.

3. Benoit RM, Naslund MJ, Cohen JK. Complications after radical retropubic prostatectomy in the Medicare population. Urology 2000;56:116-120.

4. Begg CB, Riedel ER, Bach PB, Kattan MW, Schrag D, Warren JL, Scardino PT. Variations in morbidity after radical prostatectomy. N Engl J Med 2002;346:1138-1144.

5. Kural AR, Coskuner ER, Cevik I. Holmium laser ablation of recurrent strictures of urethra and bladder neck: Preliminary results. J Endourol 2000;14:301-304.

6. Kerr LA, Zincke H. Radical retropubic prostatectomy for prostate cancer in the elderly and the young: Complications and prognosis. Eur Urol 1994;25:305-312.

7. Rassweiler J, Seemann O, Schulze M, Teber D, Hatzinger M, Frede T. Laparoscopic versus open radical prostatectomy: A comparative study at a single institution. J Urol 2003;169: 1689-1693.

8. Van Velthoven RF, Ahlering TE, Peltier A, Skarecky DW, Clayman RV. Technique for laparoscopic running urethrovesical anastomosis: The single knot method. Urology 2003;61:699-702.

9. Shelfo SW, Obek C, Soloway MS. Update on bladder neck preservation during radical retropubic prostatectomy: Impact on pathologic outcome, anastomotic strictures, and incontinence. Urology 1998;51:73-78.
10. Berlin JW, Ramchandani P, Banner MP, Pollack HM, Nodine CF, Wein AJ. Voiding cystourethrography after radical prostatectomy: Normal findings and correlation between contrast extravasation and anastomotic strictures. AJR Am J Roentgenol 1994;162:87-91.

11. Surya BV, Provet J, Johanson K-E, Brown J. Anastomotic strictures following radical prostatectomy: Risk factors and management. J Urol 1990;143:755-758.

12. Ravzi HA, Chun SS, Denstedt JD, Sales JL. Soft-tissue applications of the holmium laser in urology. J Endourol 1995;9:387-390.

13. Larizgoitia I, Pons JMV. A systematic review of the clinical effectiveness of the holmium:YAG laser in urology. BJU Int 1999;84:1-9.

14. Cornford PA, Biyani CS, Powell CS. Transurethral incision of the prostate using the holmium YAG laser: A catheterless procedure. J Urol 1998;159:1229-1231.

Address reprint requests to: Brunolf Lagerveld, M.D. Dept. of Urology Academic Medical Center University of Amsterdam

PO Box 22660

1100 DD Amsterdam, The Netherlands

E-mail: b.w.lagerveld@amc.uva.nl 